PENGARUH PEMBERIAN SAGU (Metroxylon spp) TERHADAP KADAR GLUKOSA DARAH MENCIT PUTIH JANTAN

(Mus musculus) DIABETES MELITUS

TESIS

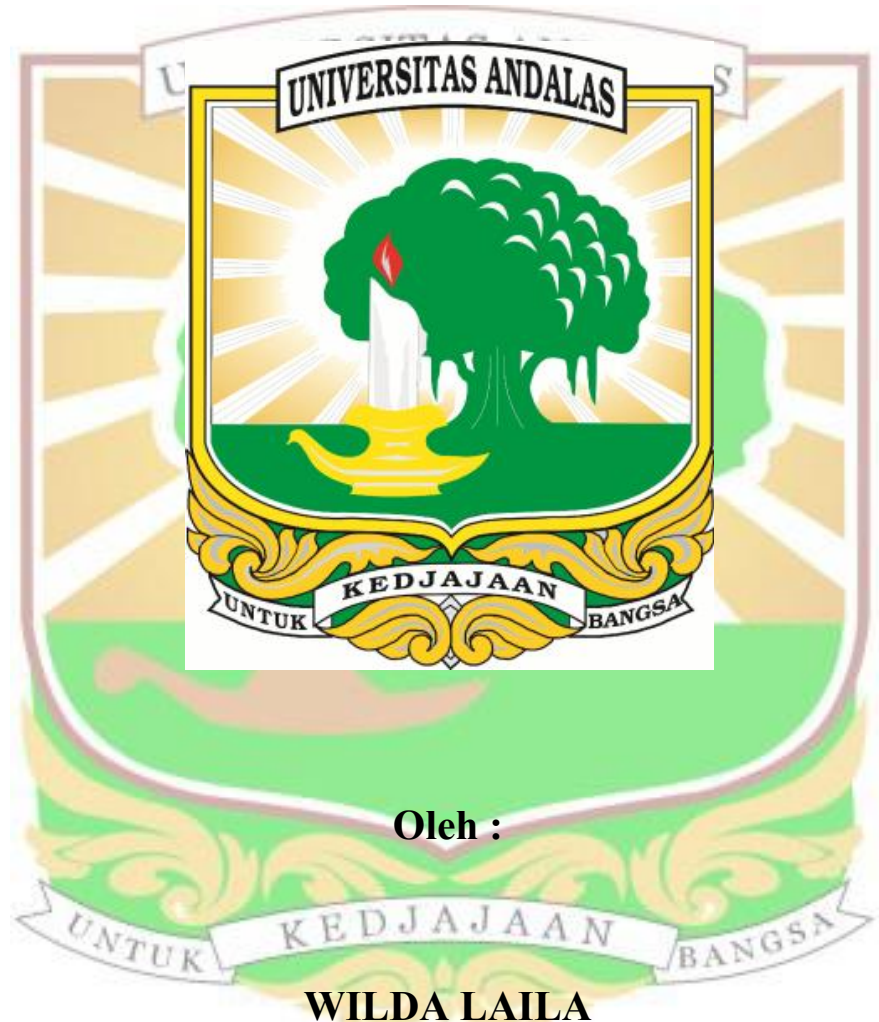

NIM.1320312007

Pembimbing: Prof. Dr. dr. Delmi Sulastri, MS, Sp.GK dr. Malinda Meinapuri, MSi, Med

PROGRAM PASCA SARJANA ILMU BIOMEDIK

FAKULTAS KEDOKTERAN

UNIVERSITAS ANDALAS

PADANG

2017 


\title{
PENGARUH PEMBERIAN SAGU (Metroxylon spp) TERHADAP KADAR GLUKOSA DARAH MENCIT PUTIH JANTAN (Mus musculus) DIABETES MELITUS
}

\author{
Oleh: Wilda Laila (1320312007) \\ (Dibawah bimbingan: Prof. Dr. dr. Delmi Sulastri, MS, Sp.GK dan \\ dr. Malinda Meinapuri, MSi, Med
}

\begin{abstract}
Abstrak
Diabetes Melitus (DM) menimbulkan berbagai komplikasi apabila tidak dikendalikan dengan baik. International Diabetes Federation (IDF, 2015) menyatakan tingkat prevalensi global penderita DM pada tahun 2014 sebesar 8,3 $\%$ yaitu sebanyak 387 juta kasus di dunia. Tujuan penelitian ini adalah untuk mengetahui pengaruh pemberian sagu (Metroxylon spp) terhadap kadar glukosa darah mencit putih jantan (Mus musculus) diabetes melitus.

Penelitian ini merupakan penelitian eksperimental dengan rancangan pretest dan post-test only group design yang dilakukan pada bulan Oktober Desember 2016. Sampel 25 ekor mencit dikelompokkan atas Kontrol Negatif ( $\mathrm{KN}$ ) diberi diet standar, Kontrol Positif (KP) diberi induksi aloksan, 3 kelompok perlakuan (P1) 65mg/20g BB/hari diberi tepung beras, kelompok (P2) 65mg/20g $\mathrm{BB} /$ hari diberi tepung sagu, kelompok (P3) $130 \mathrm{mg} / 20 \mathrm{~g} \mathrm{BB} /$ hari diberi tepung sagu. Analisa data menggunakan uji Anova dilanjutkan dengan uji Post Host Test dengan derajat kepercayaan $95 \%$.

Hasil penelitian rerata kadar glukosa darah mencit kelompok perlakuan (P2) terdapat perbedaan signifikan yaitu $\mathrm{p}$ value 0,012 , dan kelompok perlakuan (P3), menunjukkan terdapat perbedaan yang signifikan yaitu $p$ value 0,019 .

Kesimpulan dari penelitian ini adalah terdapat perbedaan rerata kadar glukosa darah setelah diberikan tepung beras dan tepung sagu pada berbagai kelompok penelitian.

Kata kunci : Sagu, Tepung Beras, Glukosa Darah, dan Diabetes Melitus
\end{abstract}




\section{THE EFFECT OF SAGO (Metroxylon spp) ON BLOOD GLUCOSE LEVEL OF MALE WHITE MOUSE (Mus musculus) WITH DIABETES MELLITUS}

By : Wilda Laila (1320312007)

Under the guidence : Prof. DR. dr. Delmi Sulastri. MS, Sp.GK dan

dr. Malinda Meinapuri, MSi./Med

Abstract

Diabetes Mellitus (DM) causes various complications if it is not controlled properly. International Diabetes Federation (IDF, 2015) stated that the prevalence DM in 2104 was $8,3 \%$ or equals to 387 million in the world. The objective of this research was to identify the influence of Sago (Metroxylon spp) on blood glucose levels of male white mouse (Mus musculus) with Diabetes Mellitus.

This research was an experimental research with pre-test and post-test only group design, conducted from October to December 2016. The samples were 25 male white mice (Mus musculus) which were divided into The negative control group was given standard diet, the positive control group was given induction of alloxan, three treatment groups (P1) $65 \mathrm{mg} / 20 \mathrm{~g}$ BW/day was given rice flour, groups (P2) $65 \mathrm{mg} / 20 \mathrm{~g}$ BW/day was given sago and P3 group was given sago $130 \mathrm{mg} / 20 \mathrm{~g}$ BW/day. The data was analysis by Anova testing and Post Host Test testing with trust degree of $95 \%$.

The result was the blood glucose level of the mice showed that there was a significant difference with $p$ value 0,012 on group (P2) with treatment, while in group treatment (P3), there was also significant difference with $p$ value 0,019.

It could be concluded that there was a significant difference in the average blood glucose level after the rice flour and sago treatment towards various groups Key word : Sago, Rice Flour, Blood Glucose Level, and Diabetes Mellitus 